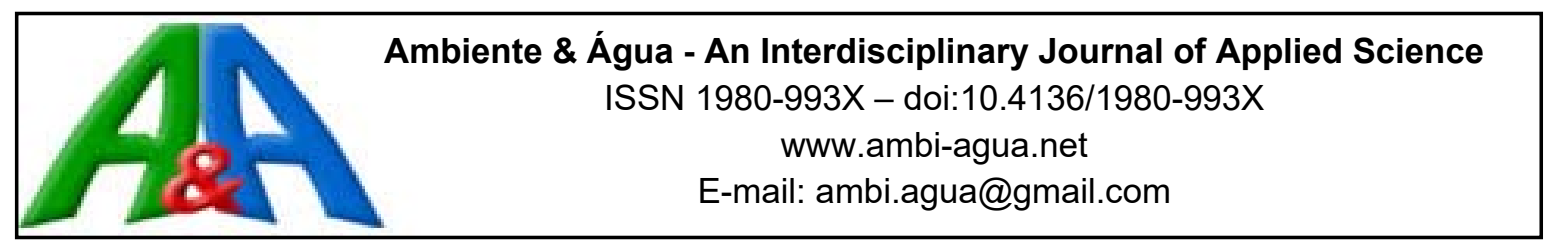

\title{
Solid phase extraction using molecular imprinting polymers (MISPE) for the determination of estrogens in surface water by HPLC
}

\author{
doi:10.4136/ambi-agua.1991 \\ Received: 19 Dec. 2016; Accepted: 15 Mar. 2017 \\ Viviane do Nascimento Bianchi; Marcos Roberto de Araujo Silva;
Marcus Augusto Lamim; Clovis Lucio da Silva;
Elizabete Campos de Lima* \\ Universidade Federal do ABC, (UFABC), Santo André, SP, Brasil \\ Centro de Ciências Naturais e Humanas \\ *Corresponding author: e-mail: elizabete.lima@ufabc.edu.br, \\ vivi.nbianchi@yahoo.com.br,marcos.araujo@ufabc.edu.br, \\ marcus.lamim@hotmail.com, clovis.silva@ufabc.edu.br
}

\begin{abstract}
Estrogens are emerging pollutants and traditional sewage treatments unable to remove them. They are harmful to human health and to the environment. It is therefore important to evaluate the presence and concentration of estrogens in water bodies and environmental matrices. This work presents the development and application of a methodology for the determination of E1, E3, EE2 and E2 in surface waters using solid phase extraction with molecular imprinting polymers (MISPE) followed by identification and quantification by HPLC-DAD. Acetonitrile and water deionized acidified with phosphoric acid pH $3(1: 1, \mathrm{v} / \mathrm{v})$, a flow rate of $1.0 \mathrm{ml} \mathrm{min}^{-1}$, at $40^{\circ} \mathrm{C}$ and an injection volume of $5 \mu \mathrm{L}$. The method was validated according to the protocol ICH Q2R. Reproducibility and repeatability tests resulted in a smaller variation coefficient of $10 \%$; the calibration curves in the concentration ranged from 1 to $20 \mathrm{mg} \mathrm{L}^{-1}$, with return linearity values greater than 0.99 . The limits of detection and quantification were less than $1 \mathrm{mg} \mathrm{L}^{-1}$ and the method was satisfactory for specificity and selectivity tests using caffeine, which is often found in water bodies receiving effluent, and DES, an estrogen used in the treatment of prostate cancer. Selected samples underwent cleanup and pre-concentration treatments using solid phase extraction with commercial phase (C18) and molecularly imprinted polymers (MISPE). The analysis of MISPE extracts indicate that it is possible to obtain results with greater sensitivity and precision for analyses of complex environmental matrices, demonstrating that the developed method can be applied in complex environmental matrices.
\end{abstract}

Keywords: emerging pollutants, endocrine disruptors, environmental matrices.

\section{Extração em fase sólida utilizando polímeros de impressão molecular (MISPE) para a determinação de estrógenos em águas superficiais por HPLC}

\section{RESUMO}

Estrogênios são poluentes emergentes e os tratamentos de esgoto tradicionais não são capazes de removê-los. São prejudiciais à saúde humana e ao ambiente. Portanto, torna-se 
importante avaliar a presença e concentração dessas substâncias em corpos hídricos e matrizes ambientais. No presente trabalho, apresenta-se o desenvolvimento e aplicação de uma metodologia para a determinação de E1, E3, EE2, E2 em águas superficiais utilizando a extração em fase sólida com polímeros de impressão molecular (MISPE) seguida da identificação e quantificação via HPLC-DAD. A fase móvel empregada foi acetonitrila e água acidificada, com ácido fosfórico, $\mathrm{pH} 3,(1: 1, \mathrm{v} / \mathrm{v})$, vazão $1,0 \mathrm{~mL} \mathrm{~min}^{-1}, 40^{\circ} \mathrm{C}$, injeção $5 \mu \mathrm{L}$ e $\lambda=280 \mathrm{~nm}$. O método foi validado segundo o protocolo ICH Q2 R1. Testes de reprodutibilidade e repetibilidade resultaram em coeficientes de variância menores que $10 \%$, e as curvas de calibração na faixa de concentração de 1 a $20 \mathrm{mg} \mathrm{L}^{-1}$ retornaram valores de linearidade maiores que 0,99 . Os limites de detecção e quantificação ficaram abaixo de $1 \mathrm{mg} \mathrm{L}^{-1}$ e o método mostrou-se satisfatório para testes de especificidade e seletividade usando cafeína encontrada em corpos hídricos que recebem efluentes, e DES, estrogênio utilizado em tratamento de câncer de próstata. Amostras selecionadas foram submetidas a clean-up e pré-concentração utilizando extração em fase sólida com fase comercial $(\mathrm{C} 18)$ e polímeros de impressão molecular (MISPE). Os extratos MISPE analisados indicaram que é possível obter resultados com maior sensibilidade e precisão para análises de matrizes ambientais complexas; mostrando que o método desenvolvido pode ser aplicado em matrizes ambientais complexas.

Palavras-chave: disruptores endócrinos, matrizes ambientais, poluentes emergentes.

\section{INTRODUCTION}

Emerging pollutants are defined as compounds of varied origins - pharmaceuticals, illicit drugs, personal care products, industrial additives, among others - that can be found in environmental and biological matrices, which often not controlled by regulatory agencies although they may pose a potential risk to human health and the environment (Naidu et al. 2016). Potential risks to human health and the environment include dysfunctions in the endocrine and reproductive systems of humans and animals, miscarriages, metabolic disorders and incidence of malignant neoplasms, as well as the introduction of resistant bacteria (Noguera-Oviedo and Aga, 2016).

The contamination of water resources is currently one of the main environmental problems, and the concern with micropollutants, substances found in concentrations in the order of $\mu \mathrm{g} \mathrm{L}^{-1}$ and $n g \mathrm{~L}^{-1}$, has recently increased (Bila and Dezotti, 2007) because they are capable of seriously harming living beings, despite the low concentrations in which they are detected. Hormones stand out from the substances that can be classified as micropollutants. Due to their damaging effects on the environment, it is necessary to develop techniques that detect and extract these substances from the aquatic environment. The impacts triggered by these substances on the environment are considered a matter of global scope, and can be observed from microinvertebrates to large vertebrates (Reis Filho et al., 2006).

Sexual hormones, one of the various classes of hormones, have greater relevance in the study of the contamination of effluents. Sexual hormones can be classified into female sex hormones, called estrogens, male hormones, known as androgens and pregnancy hormones or progestogens (Naidu et al., 2016; Reis Filho et al., 2006).

Estrogens are a group of hormones with similar chemical structure and effects in the estrous cycle, capable of acting as endocrine disruptors. In the aquatic environment, the effects of these compounds are not completely understood; but some damages have been observed, such as feminization of fish (Van Donk et al., 2016) and changes in physiological and reproductive behavior, including damages caused by progesterone (Figure 1), which acts as a reproductive hormone (Chang et al., 2011; Wang et al., 2015). 
Estrogens can be produced naturally by the human body, such as $\beta$-Estradiol(E2), estrone (E1) and estriol (E3); or may be synthetic, such as 17 $\alpha$-Ethynylestradiol (EE2) and mestranol(MeEE2) (Reis Filho et al., 2006). Figure 1 shows the molecular structures of these compounds.

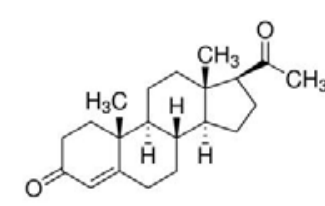

Progesterone

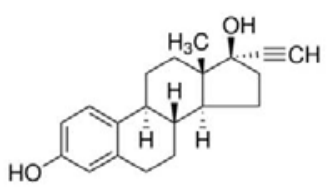

$17 \alpha$-ethinylestradiol

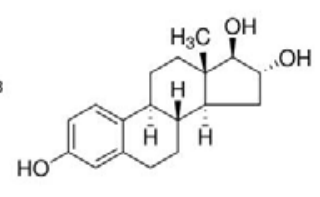

Estriol

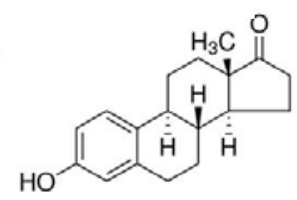

Estrone

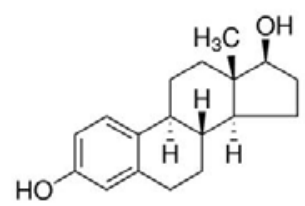

$\beta$-Estradiol

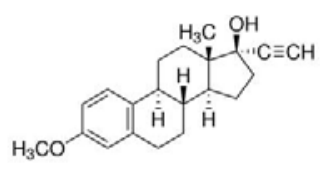

Mestranol

Figure 1. Molecular structure of the hormones progesterone (PROG), estriol (E3), $\beta$-estradiol (E2), 17 $\alpha$-ethinyl estradiol (EE2), estrone (E1) and mestranol (MeEE2).

The study by Liu and coworkers (Liu et al., 2015) estimated the natural estrogen excretion rates in some countries, and found Brazil to have the highest rate for E2 and E3 among countries as China, Korea, Japan, Iran, Turkey, Italy, Canada and the United States.

In order to better control the chemical compounds considered potentially emerging pollutants of interest in effluents, it is necessary to know the concentration of these compounds not only in natural water bodies but also in artificial water bodies and in water supply for human consumption (Nelson et al., 2010).

The most commonly used chemical instrumental analytical technique for determining hormones is high performance liquid chromatography (HPLC) coupled with different detection systems. In a review study, Gabet et al. (2007), Naidu et al. (2016), and Noguera-Ovedo and Aga (2016) gathered published papers from 1999 to 2007 highlighting information on hormone analysis in environmental matrices. In sample preparation prior to HPLC analysis, the most commonly used technique was filtration, solid phase extraction and online sample preparation. The most common techniques used for analysis were HPLC-MS, GC-MS and HPLC-MS / MS. Of the collected works, only one author used liquid chromatography with a DAD detector, resulting in limits of quantitation and detection higher than those obtained by HLC-MS. Therefore, the objective of the present work is to demonstrate the use of solid phase extraction with molecular imprinting polymers (MISPE) as an alternative clean-up and preconcentration methodology for the identification and quantification of estrogen hormones in surface water samples by HPLC-DAD. In sum, the main objective is to show the advantage of using a simple and sensitive preconcentration and clean-up technique and a more accessible detection system than an HPLC-MS system.

\section{MATERIAL AND METHODS}

A high-performance liquid chromatography (HPLC) method was developed for the determination of estrogens following the instructions provided by Snyder et al. (1997) and using as a starting point the study by Daniel and Lima (2014). An Agilent 1220 HPLC-DAD with 
automatic injector, a column furnace, OpenLAB revision A.01.05 data acquisition software, and a diode network detection system (DAD) were used to perform this work, with a Phenomenex kinetex C18 column $(30 \mathrm{~mm} \times 2,1 \mathrm{~mm} \times 5 \mu \mathrm{m})$. The parameters of the method were as follows: isocratic mode, mobile phase $50: 50 \mathrm{v} / \mathrm{v}$ acidified water with orthophosphoric acid (PA, LabSynth) (20 $\mu$ l of acid / L ultrapure water) and acetonitrile (HPLC grade, JT Baker), flow $1,0 \mathrm{~mL} \mathrm{~min}{ }^{-1}$, injection volume of $5 \mu \mathrm{L}$, temperature of $40^{\circ} \mathrm{C}$, reading in $\lambda=280 \mathrm{~nm}$, as described by Daniel and Lima (2014). In the same proportion of the mobile phase, stock solutions of estriol (E3), estrone (E1), 17 $\alpha$-ethinylestradiol (EE2), $\beta$-estradiol (E2), mestranol MeEE2) and progesterone (PROG) (all from Sigma Aldrich) were prepared in acetonitrile and water, in the concentration of $50 \mathrm{mg} \mathrm{L}^{-1}$. From these stock solutions, mixes of hormones in the concentration range of 1 to $20 \mathrm{mg} \mathrm{L}^{-1}$ were prepared.

The HPLC methodology developed as well as the solid phase extraction process were validated according to the protocol ICH Q2R1 (ICH, 2005). For this, tests were performed using a $10 \mathrm{mg} \mathrm{L}^{-1}$ hormone mix for repeatability and reproducibility and the respective coefficients of variance were calculated. A calibration curve was made with samples in the concentration range of 1 to $20 \mathrm{mg} \mathrm{L}^{-1}$, through which the linearity can be evaluated. In order to calculate the limits of detection and quantitation, the signal to noise ratio, $\mathrm{S} / \mathrm{N}$, was analyzed in a ratio of 3:1 for detection and 10:1 for quantification. To determine the specificity and selectivity, two compounds were used: caffeine (analytical standard in water, Agilent) and diethylstilbestrol (DES, Sigma Aldrich), adding $10 \mu \mathrm{L}$ of standard solution with a concentration of $50 \mathrm{mg} \mathrm{L}^{-1}$ to the mix previously used to provide repeatability and reproducibility.

\subsection{Extraction and preconcentration of hormones in surface water}

For extraction simulated samples with ultrapure water and simulated samples with tap water were prepared in triplicate by adding a standard solution of the mixed hormones, leading to a final concentration of $1 \mathrm{mg} \mathrm{L}^{-1}$. Duplicate samples of surface water collected in the subsurface region next to the discharge point of the Sewage Treatment Plant Pinheirinho, in the Alvarenga Arm of the Billings Dam. The water collected was kept in a thermal box for transporting and was then frozen until the day of the extraction procedure.

To begin, commercial C18 cartridges were washed with $3 \mathrm{~mL}$ of water, followed by $3 \mathrm{~mL}$ of methanol; $50 \mathrm{ml}$ of each sample was used for extraction. After passing this volume of sample through the cartridge, $3 \mathrm{~mL}$ of 50:50 v/v mixture of water and methanol was used to elute the retained compounds. The contents were eluted in test tubes and evaporated to dryness under nitrogen gas flow (99.9\% purity); then the samples were dissolved in $250 \mu \mathrm{l}$ of the mobile phase for analysis by the developed HPLC method. As an alternative, molecular imprinting polymer was used in the solid phase extraction of simulated samples with standard solutions.

The imprinting polymer was synthesized in a test tube using $2 \mathrm{~mL}$ of a $10 \mathrm{mg} \mathrm{L}^{-1}$ standard solution in acetonitrile of estriol, as template molecule (target analyte), $0.17 \mathrm{~mL}$ of methacrylic acid, $1.333 \mathrm{~mL}$ of ethylene glycol and $0.015 \mathrm{~g}$ of 2,2-azobisisobutyronitrile. The mixture was kept in a $60^{\circ} \mathrm{C}$ bath for 20 hours. The polymer was removed from the tube, oven dried at $40^{\circ} \mathrm{C}$ for 2 hours and triturated. The template molecule was removed by placing the polymer with $3 \mathrm{~mL}$ of methanol in ultrasonic bath for 5 minutes. After drying at room temperature, the polymer was placed in recycled extraction cartridges where the commercial stationary phase was replaced by the synthesized MISPE phase. The extraction procedure described for C18 cartridge was repeated for a simulated sample containing E3, E2, EE2 and E1 at the concentration of $1 \mathrm{mg} \mathrm{L}^{-1}$. The extracts obtained were analyzed comparatively (Figure 3 ). 


\section{RESULTS AND DISCUSSION}

\subsection{Development and optimization of the method}

The method was developed and optimized for the parameters of mobile phase proportion and temperature, until the best separation for the six hormones was obtained. The optimized mobile phase consisted of acetonitrile and acidified water in the ratio of 50:50 (v/v) and temperature of $40^{\circ} \mathrm{C}$, flow $1 \mathrm{~mL} \mathrm{~min}^{-1}$. To identify the corresponding peak for each analyte, $10 \mu \mathrm{L}$ of standard solution of each analyte was added at a time, and the mix was reanalyzed. Thus, by increasing the concentration of a compound, the intensity of its peak consequently increased so that the peak and its corresponding analyte were easily identified. To calculate the resolution obtained with the method under these conditions, a chromatogram (Figure 2) obtained for a mix of hormones containing E3, E2, EE2 and E1, mestranol (MeEE2) and progesterone (PROG) was used.

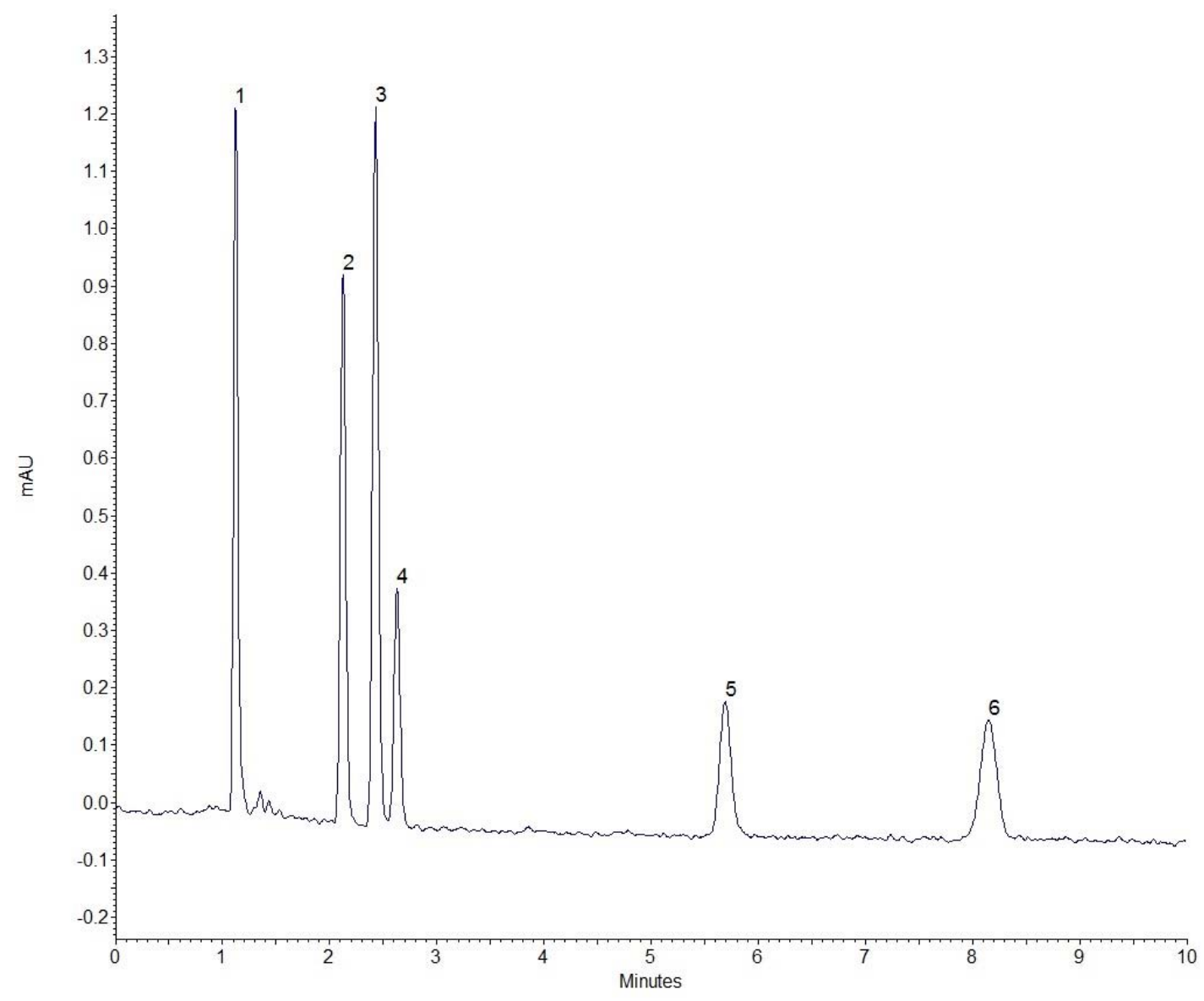

Figure 2. Amplified chromatogram of a mix at the concentration of $5 \mathrm{mg} \mathrm{L}^{-1}$ of the hormones studied. Analytical conditions: isocratic mode, mobile phase (50:50, v / v), deionized water acidified with orthophosphoric acid $\mathrm{pH} 3$, and HPLC grade acetonitrile, $1.0 \mathrm{~mL} \min -1$ flow, $5 \mu \mathrm{L}$ injection volume, $40^{\circ} \mathrm{C}, \lambda=280 \mathrm{~nm}$. The peaks refer to (1) E3, (2) E2, (3) EE2, (4) E1, (5) PROG, (6) MeEE2.

The obtained peaks had very good resolution values, i.e., resolution over 2 for all pairs of peaks; that is desirable when it comes to method development, except for the critical pair, peaks 3 and 4, i.e., EE2 / E1, presenting a value greater than 1.5, compatible for bands of similar sizes. Table 1 shows the resolution values obtained for each pair of analytes according to the chromatogram of Figure 2. 
The constant temperature at $40^{\circ} \mathrm{C}$ contributed to the good resolution, because, due to the increase in temperature the retention factor also increases and consequently the resolution improves (Snyder et al., 1997).

Table 1. Resolution obtained for the analytes studied in the method developed.

\begin{tabular}{lc}
\hline \multicolumn{1}{c}{ Pairs of peaks } & Resolution \\
\hline Estriol / $\beta$-estradiol(E3/E1) & 7.25 \\
$\beta$-estradiol / 17 $\alpha$-etinilestradiol (E2/EE2) & 2.20 \\
17 $\alpha$-ethinylestradiol / Estrone (EE2/E1) & 1.64 \\
Estrone / Progesterona (E1/PROG) & 15.84 \\
Progesterone / Mestranol (PROG/MeEE2) & 8.11 \\
\hline
\end{tabular}

\subsection{Validation of the method}

From the chromatogram of the $5 \mathrm{mg} \mathrm{L}^{-1}$ hormone mix with all peaks duly identified, the detection and quantification limits were calculated following the signal-to-noise ratio of 3:1 and 10: 1, respectively, for each analyte. The values found are shown in Table 2.

Table 2. Detection Limit Values and Quantification Limits for the hormones studied.

\begin{tabular}{lcc}
\hline Analyte & Detection Limit $\left(\mathrm{mg} \mathrm{L}^{-1}\right)$ & Quantification Limit $\left(\mathrm{mg} \mathrm{L}^{1}\right)$ \\
\hline Estriol (E3) & 0.12 & 0.41 \\
$\beta$-estradiol (E2) & 0.16 & 0.54 \\
17 $\alpha$-ethinylestradiol (EE2) & 0.12 & 0.41 \\
Estrone (E1) & 0.39 & 1.32 \\
Progesterone (PROG) & 0.83 & 2.77 \\
Mestranol (MeEE2) & 0.94 & 3.13 \\
\hline
\end{tabular}

The values found were satisfactory considering that they were micro-pollutants. However, these values are still higher than those obtained in studies using mass spectrometer detector (Gabet et al., 2007). It is therefore suggested that the use of a sample preconcentration step would be ideal.

Using a $10 \mathrm{mg} \mathrm{L}^{-1}$ hormone mix, the precision of the method was evaluated through intra-assay and inter-assay coefficients of variance. The values obtained are shown in Table 3 . The values were mostly below $2 \%$, with the exception of E1. According to Snyder et al. (1997), the accuracy should be close to $2 \%$. The ICH Q2R1 protocol does not specify the limit of the coefficient of variance.

Another parameter evaluated in the validation is the accuracy, that is, the proximity of the measured values to the actual values. For that, three concentrations of the extension of the calibration curve were used, in triplicate. The values are presented in Annex A. Accuracy values should be up to $2 \%$ or be between $10 \%$ and $20 \%$ when dealing with traits according to Snyder et al. (1997). Thus, the values are satisfactory for PROG, EE2 and E2. For the other hormones, the values are lower than $20 \%$; however, considering the concentration of $20 \mathrm{mg} \mathrm{L}^{-1}$, the accuracy is high, especially for E3 and E1. A possible contributing factor to increase this error is the standard solution used. There is no ready standard solution for these hormones, and it is necessary to prepare them from the solid compound. Therefore, the stock solution is susceptible to errors in weighing and dissolving the hormones. 
Table 3. Values of the coefficient of variance for intra- and interassay of the method developed for the six hormones.

\begin{tabular}{lcc}
\hline Analito & Intra-assay & Inter-assay \\
\hline Estriol & $1.55 \%$ & $4.31 \%$ \\
$\beta$-estradiol & $1.22 \%$ & $1.60 \%$ \\
$17 \alpha$-ethinylestradiol & $0.72 \%$ & $0.80 \%$ \\
Estrone & $2.72 \%$ & $3.23 \%$ \\
Progesterone & $1.32 \%$ & $1.97 \%$ \\
Mestranol & $1.61 \%$ & $2.67 \%$ \\
\hline
\end{tabular}

The calibration curve was made in the range of 1 to $20 \mathrm{mg} \mathrm{L}^{-1}$ concentration, with five points. The linearity obtained with the curves was very satisfactory, presenting $\mathrm{r}^{2}$ values greater than 0.999 . In order to verify the specificity of the method, the compound diethylstilbestrol (DES), a synthetic estrogen, was added to the standard mix.

In addition to DES, caffeine was added to the sample because it is a compound commonly found in effluent samples. The separation was effective, demonstrating the specificity of the method. The separation of the eight compounds applying the developed method can be observed in Figure 3.

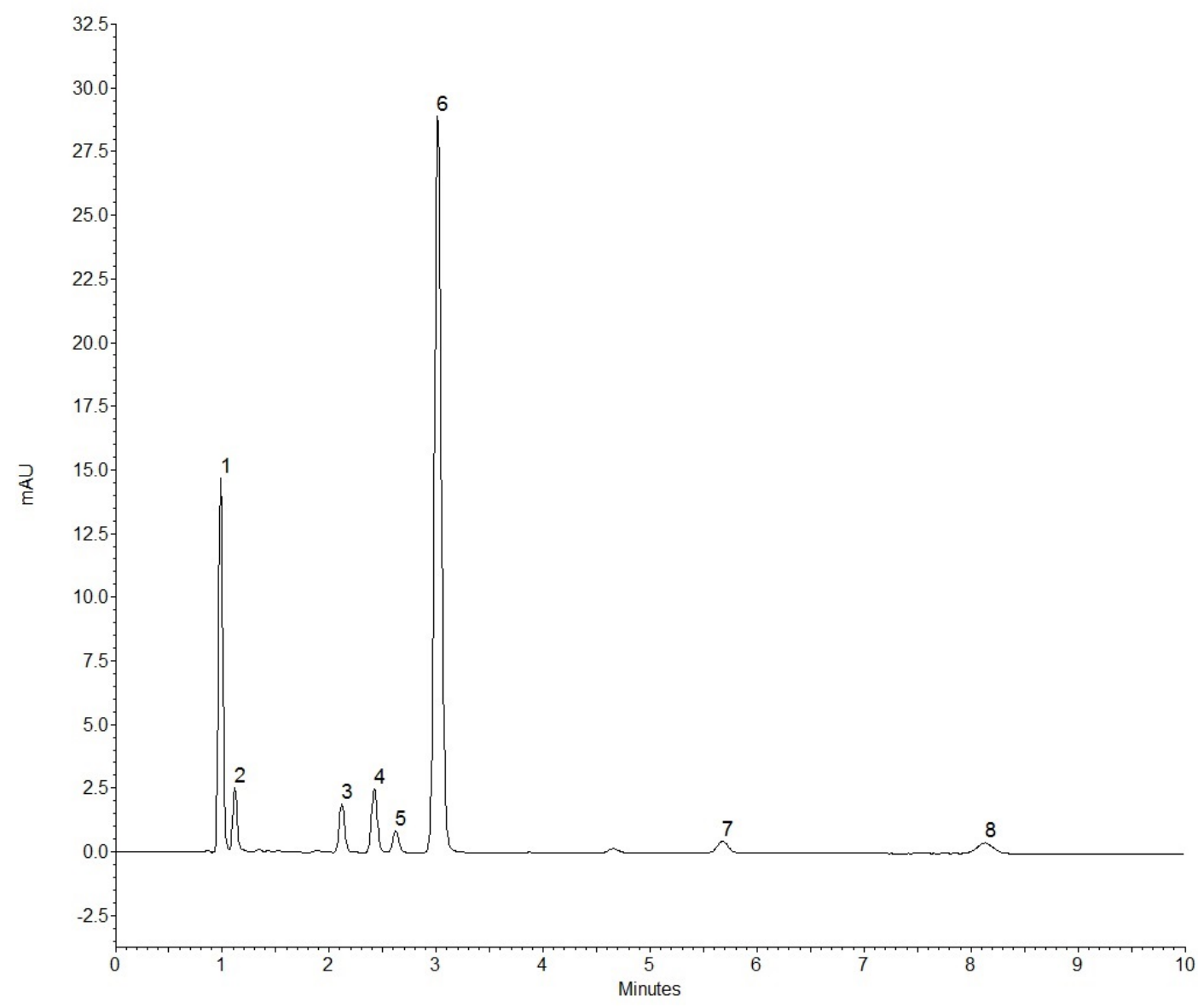

Figure 3. Chromatogram obtained after the addition of DES and caffeine, showing the separation for (1) caffeine, (2) E3, (3) E2, (4) EE2, (5) E1, (6) DES, (7) PROG and 8) MeEE2. Analytical conditions: isocratic mode, mobile phase $(50: 50, \mathrm{v} / \mathrm{v})$ deionized water acidified with orthophosphoric acid $\mathrm{pH} \mathrm{3}$, and HPLC grade acetonitrile, $1.0 \mathrm{~mL} \mathrm{~min}^{-1}$ flow, $5 \mu \mathrm{L}$ injection volume, $40^{\circ} \mathrm{C}, \lambda=280 \mathrm{~nm}$. 


\subsection{Simulated Sample Analysis and real Sample}

The simulated and collected samples submitted to the solid phase extraction (SPE) with commercial cartridge were analyzed using the validated method. However, no analyte could be identified. However, the fact that the extracts analyzed by the validated methodology did not result in a chromatogram with peaks suggests the $\mathrm{C} 18$ commercial phases do not promote clean-up and preconcentration with adequate sensitivity for the determination of trace levels of hormones. However, replacing the commercial phase $\mathrm{C} 18$ by the molecular imprinting polymer synthesized with estriol (E3) as template and applying the same procedure of the extraction, the analysis returned satisfactory results, as shown in Figure 4.

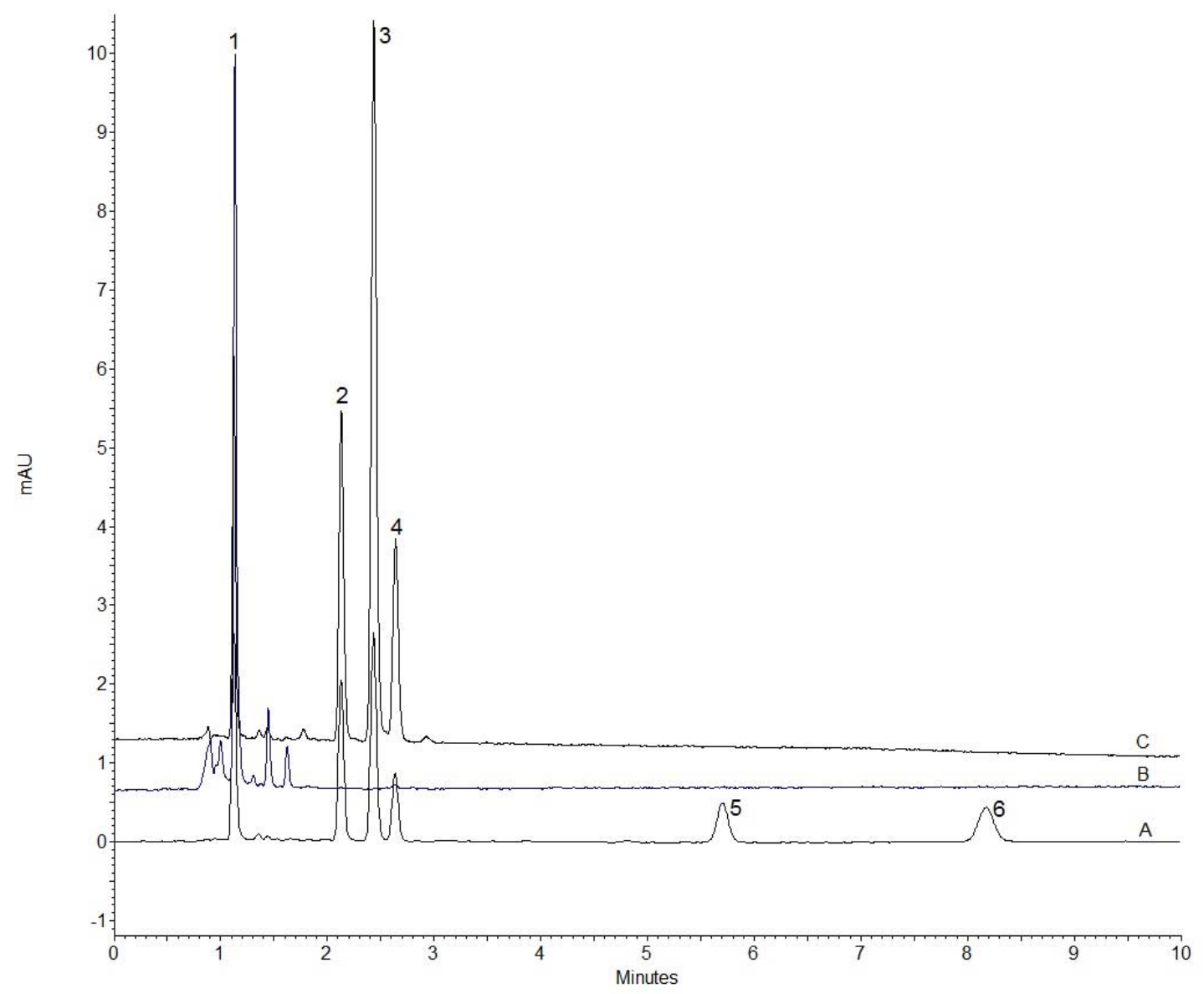

Figure 4. Chromatograms obtained for sample of estrogen hormone mix (1) E3, (2) E2, (3) EE2, (4) E1, (5) PROG, (6) MeEE2: (A) B) chromatogram of the SPE extract using commercial C18 cartridge and $(C)$ extract chromatogram using SPE with MIP phase synthesized in the laboratory. Analytical conditions: isocratic mode, mobile phase (50:50, v/ v) deionized water acidified with orthophosphoric acid $\mathrm{pH} 3$, and HPLC grade acetonitrile, $1.0 \mathrm{~mL} \mathrm{m^{-1 }}$ flow, $5 \mu \mathrm{L}$ injection, $40^{\circ} \mathrm{C}, \Lambda=280 \mathrm{~nm}$.

Because of the similar molecular structure, the estrogen hormones present in the simulated sample, in this case, estriol, $\beta$-estradiol, $17 \alpha$-ethinyl estradiol and estrone, were expected to be retained at the active sites and extracted from the sample. The results were compatible with the expected results, since in the simulated sample analysis the four hormones were identified. Therefore, the method proved to be effective in the proposed application and it was possible to highlight the potential of the molecular imprinting polymers for clean-up and pre-concentration of the analytes in complex matrices like the environmental samples. The sample of the Pinheirinho station analyzed showed the presence of $17 \alpha$-ethinylestradiol (EE2); but it was only 
possible to perform the spectral identification of the same using the spectrum analysis feature that the Agilent 1220 HPLC with the DAD detector allows, because the EE2 peak has a height and area below the limit of detection obtained by the validated methodology.

As can be observed, MIPs play an important role in the preparation of samples for chromatographic analysis, as shown by the work of Castillo-García et al. (2016) in which a survey from 2011 to 2015 found that $17.2 \%$ of the published papers used MIPs for sample preparation. This demonstrates the versatility, applicability and importance of these materials in preparation of samples for chromatographic analysis.

\section{CONCLUSIONS}

The developed method is simple, resulted in excellent resolution for the separation of the six hormones studied, with excellent linearity in the range of 1 to $20 \mathrm{mg} \mathrm{L}^{-1}$. The values for coefficient of variance and accuracy were good and the method was specific with very good separation of eight compounds, which are these hormones and the interfering caffeine and DES (diethylstilbestrol). The limits of detection and quantitation are in the order of microgram per liter, thus it may be better to analyze samples after preparation techniques that concentrate the analytes. An alternative is the application of solid phase extraction with molecular imprinting polymers, which seemed to be effective in applying the developed and validated method. Future studies involve the synthesis, characterization and application of these polymers and the method and afterwards for the inclusion of more environmentally important hormones as well as other classes of endocrine disruptors. It is also necessary to improve the sensitivity of the synthesized MISPE phases to minimize matrix effects.

\section{ACKNOWLEDGEMENTS}

We thank FAPESP Process 2013/12569-8 for the research support.

\section{REFERENCES}

BILA, D. M.; DEZOTTI, M. Desreguladores endócrinos no meio ambiente: efeitos e consequências. Química Nova, v. 30, p. 651-666, 2007. http://dx.doi.org/10.1590/ S0100-40422007000300027

CASTILlO-GARCÍA, M. L.; AGUILAR-CABALLOS, A.; GÓMEZ-HENZ. Nanomaterials as tools in chromatographic methods. Trends in Analytical Chemistry, v. 82, p. $385-$ 393, 2016. http://dx.doi.org/10.1016/j.trac.2016.06.019

CHANG, H.; WAN, Y.; WU, S.; FAN, Z.; HU, J. Occurrence of androgens and progestogens in wastewater treatment plants and receiving river Waters: Comparison to estrogens. Water Research, v. 45, p. 732-740, 2011. http://dx.doi.org/10.1016/j. jhazmat.2009.06.135

DANIEL, M. da S.; LIMA, E. C. de. Determinação simultânea de estriol, $\beta$-estradiol, $17 \alpha$-etinilestradiol e estrona empregando-se extração em fase sólida (SPE) e cromatografia líquida de alta eficiência (HPLC). Revista Ambiente \& Água, v. 9, p. 688695, 2014. http://dx.doi.org/10.4136/ambi-agua.1346

GABET, V.; MIÈGE, C.; BADOS, P.; COQUERY, M. Analysis of estrogens in environmental matrices. Trends is Analytical Chemistry, v. 26, n. 11, p. 1113-1131, 2007. http://dx.doi.org/10.1016/j.trac.2007.10.003 
INTERNATIONAL CONFERENCE ON HARMONISATION OF TECHNICAL REQUIREMENTS FOR REGISTRATION OF PHARMACEUTICALS FOR HUMAN USE (ICH). Validation of analytical procedures: text and methodology Q2(R1). Ottawa, 2005.

LIU, Z.; LU, G.; HUA, Y.; DANG, Z. Estimated human excretion rates of natural estrogens calculated from their concentrations in raw municipal wastewater and its application. Environmental Science and Pollution Research, v. 22, p. 9554 - 9562, 2015. http://dx.doi.org/10.1021/es035342u

NAIDU, R.; ESPANA, V.; LIU, Y.; JOYTTISHNA, J. Emerging contaminants in the environment: Risk-based analysis for better management. Chemosphere, v. 154, p. 350357, 2016. http://dx.doi.org/10.1016/j.chemosphere.2016.03.068

NELSON, E. D.; DO, H.; LEWIS, R. S.; CARR, S. A. Diurnal variability of pharmaceutical, personal care product, estrogen and alkylphenol concentrations in effluent from a tertiary wastewater treatment facility. Environmental Science \& Technology, v. 45, p. 1228 1234, 2010. http://dx.doi.org/10.1021/es102452f

NOGUERA-OVIEDO, K.; AGA, D. S. Lessons learned from more than two decades of research on emerging contaminants in the environment. Journal of Hazardous Materials, v. 316, p. 242-251, 2016. http://dx.doi.org/10.1016/j.jhazmat.2016.04.058

REIS FILHO, W. R.; ARAUJO J. C.; VIEIRA, E. M. Hormônios sexuais estrógenos: contaminantes bioativos. Química Nova, v. 29, p. 817-822, 2006. http://dx.doi.org/10.1590/S0100-40422006000400032

SNYDER, L. R.; KIRKLAND, J. J.; GLAJCH, J. L. Practical HPLC Method Development. $2^{\text {nd }}$ Ed. New Jersey: Wiley, 1997. p. 22-92

VAN DONK, E.; PEACOR, S.; GROSSER, K.; DOMIS, L. N. De S.; LÜRLING, M. Pharmaceuticals May Disrupt Natural Chemical Information Flows and Species Interactions in Aquatic Systems: Ideas and Perspectives on a Hidden Global Change. Reviews of Environmental Contamination and Toxicology, v. 238, p. 91-105, 2016. http://dx.doi.org/10.1007/978-3-319-30791-6

WANG, Y.; WANG, Q.; HU, L.; LU, G.; LI, Y. Occurrence of estrogens in water, sediment and biota and their ecological risk in Northern Taihu Lake in China. Environmental Geochemistry Health, v. 37, p. 147-156, 2015. http://dx.doi.org/10.1007/s10653-0149637-0 